\title{
DIACHRONIC PERSPECTIVE IN TEXT AND DISCOURSE STUDIES: REVIEW OF APPROACHES ${ }^{1}$
}

\author{
Elena Yu. Ilyinova \\ Volgograd State University, Volgograd, Russian Federation \\ Larisa A. Kochetova \\ Volgograd State University, Volgograd, Russian Federation
}

\begin{abstract}
The article is devoted to scientific observation of historically- and socially-oriented discourse studies (historical discoursology) that are presented by means of various approaches and research traditions. The authors give a review of several well-established subfields in diachronic discourse studies of language units and text types, namely historical pragmatics, historical text linguistics, diachronic discourse analysis, with the focus on the tools and methodology employed to investigate historical changes in language-in-use practice. It is stated that in Russian linguistics the diachronic aspect of language units functioning has been studied so far within the framework of diachronic stylistics with the purpose to define via the analysis of language unit realizations semantic and functional potentials of language units and text constituents, to distinguish text composition with its dependency on social and cultural circumstances of text production, to discover synchronic / diachronic perspectives in general and specific discourse categories evolution. The authors make a suggestion that the use of corpus methods in the diachronic discourse studies might considerably enhance the perspectives of finding out some prototypical features of discourse and their historical variations, if a research is based on text collections (text data) that are being analyzed with the corpus analysis protocols, strictly set historical periods and general reference to a certain textual cultures. The clearly defined corpus data could certainly help in retrieving information on cognitive, social, cultural, pragmatic aspects of the discourse type represented in the text collection of a historical period under study. The further comparison of the data in particular historical periods and / or regional references opens the ways for discovering diachronic vectors in the discourse type development through stating changes, transformations, replacements in the discursive forms and genres.
\end{abstract}

Key words: discourse, historical discourse studies, historical linguistics, historical pragmatics, diachrony, corpus.

\section{СОВРЕМЕННЫЕ НАПРАВЛЕНИЯ ИЗУЧЕНИЯ ТЕКСТА И ДИСКУРСА В АСПЕКТЕ ДИАХРОНИИ ${ }^{1}$}

\section{Елена Юрьевна Ильинова}

Волгоградский государственный университет, г. Волгоград, Российская Федерация

\author{
Лариса Анатольевна Кочетова
}

Волгоградский государственный университет, г. Волгоград, Российская Федерация

Аннотация. Статья посвящена научному анализу ряда работ в рамках относительно новой области современной лингвистики - исторически и социально ориентированного изучения дискурса (исторической дискурсологии), которая представлена различными направлениями и исследовательскими традициями. Дается обзор нескольких подходов к изучению языковых и текстовых знаков дискурсивной практики, утвердившихся в парадигме современной лингвистики, в частности, детально рассматривается проблематика истори- 
ческой прагматики, исторической дискурсивной лингвистики, диахронической дискурсивной лингвистики. Отмечается, что в отечественной лингвистической традиции диахроническое функционирование языка часто изучается в русле диахронической стилистики, в которой с помощью разных методов и приемов решаются поставленные исследователями задачи, в том числе анализируется семантический и функциональный потенциал единиц языка и конституентов текста, выявляются особенности композиции и социокультурный контекст порождения текста, что позволяет лингвистам устанавливать значимые категории дискурса в синхронно-диахронной перспективе. Авторы полагают, что использование корпусной методологии в диахроническом изучении дискурса существенно расширяет перспективы установления прототипических характеристик и признаков дискурса, поскольку корпусные методы позволяют исследовать коллекции текстов (текстовые массивы) в соответствии с заданными историческими периодами в истории языка и текстовой культуры в целом и создают возможности извлечения как собственно языковых фактов, так и данных о когнитивных, социальных, культурных, прагматических аспектах дискурса, характерного для отдельного исторического периода. Сравнение полученных данных по отдельным периодам и / или региональной отнесенности позволяет установить диахронические векторы развития форм дискурса, выявить процессы изменений, трансформаций, замены дискурсивных форм и жанров.

Ключевые слова: дискурс, историческая дискурсология, историческая лингвистика, историческая прагматика, диахрония, корпус.

\section{Introduction}

It is evident that a general trend in modern linguistics development should be described in the light of an integrated approach based on studies of language-in-use aimed at discovering a multifunctional role of language units and semantic representation of the social world construal in textual forms. Following it linguists consider the language units markers of cognitive, social, cultural information decoded in communication practice, they are thought to be mental activity representations of people who belong to a community that resides in a definite place, at a definite time period and feels the need to communicate in a certain historically defined circumstances. Thus, in the course of research language forms are being viewed in terms of cognitive patterns of world perception and their semantic reflection in the language system with respect to social, cultural, psychological factors of their realization in speech practice at a specific time period. This approach to language-in-use studying has been developed in the cognitive-and-discursive paradigm of linguistic knowledge $[1 ; 6 ; 7 ; 25 ; 43$ et al.]. As it is focused on detailed consideration of the ways every language unit performs, two basic functions cognitive and discursive are distinguished; the cognitive aspect presupposes analysis of mental construal of world perception reflected in the system of language units, the discursive interpretation allows to state the ways these units are referred to for realization of pragmatic goals in communication. Some linguists stated that the cognitive-anddiscursive paradigm allows to discover realistic markers of mental activity represented partially in speech activity caused by social reality stand points [25, p. 519-520].

The general agreement on higher scientific productivity of a research based on the integrated cognitive-and-discursive approach is overshadowed with a discussion about time span of discourse studies. The discourse is usually defined as a model of on-line language usage, which means time and space limitation of the speech activity associated with a certain type of social reality and verbal behavior [1, p. 137; 20; 38]. However, in the works of E.S. Kubryakova [25, p. 525-526], an alternative argumentation was given, it motivates possibility of referring methods and tools of cognitive-anddiscursive analysis to discourse in historical perspective: «Discourse is a creation of a certain time period» $[25$, p. 526]. Fully supporting this statement, we consider that any type of social activity is historically dependent; it is mirrored in discourse practice that absorbs social and cultural imprint and represents them in language signs chosen by a person to built texts and make them discourse products. It allows to take up linguistic studies of a group of texts (text family) that perform common functions in communicative situations and reflect a definite cultural and historic time period in evolution of a certain type of discourse. Analyzing linguistic representations of discourse categories in a text family researchers may not only disclose facts and events from national history, collect information on phonomorphological, lexical and grammatical features of the language at different time periods, but also reconstruct the first treats of 
text type formation, observe realizations of text categories in historical perspective, distinguish vectors of discourse evolution in later stages of textual culture development.

The purpose of this paper is to briefly explore and summarize the main achievements of Western discourse analysis oriented at historical approach and give a comprehensive picture of studies in Russian schools of historical linguistics that has various overtones and nuances with the accent on diachronically oriented discourse analysis.

\section{Historical linguistics and discourse studies: towards integration of approaches}

Considering the text to be a core constituent of discourse, linguists introduced historical perspective in its description. In European and American linguistics it was not until the middle 1990s' when historical linguists had reached well beyond the sentence boundary, thus switching with some delay from studies of the language system to research of language-in-use [18]. Linguists working in the field mainly do it within two subfields.

Firstly, we will point to historical pragmatics, a brunch exploring the evolution of pragmatic functions of language units in two directions: 1) from function to form, when changes in language means employed in functional units (speech acts) are studied; 2) from form to function, when changes in the functional load and/or functional repertoire of separate linguistic units are registered. In fact, this trend is often viewed as a discourse-oriented historical linguistics, the aim of which is to study pragmatic factors which influence historical language changes in the text; discursive motivations are in the focus of studies at any level of language phonological, morphological, syntactic, semantic [19].

Secondly, historical discourse linguistics is distinguished [4], it employs various methodological approaches of historical linguistics but also uses its own set of research tools for getting new goals and objectives while studying language recourses and text peculiarities in historical perspective, that is in a defined time period. It should be stated that historical discourse linguists deal mainly with texts of past periods (historical texts, documents and chronicles); they describe language and text peculiarities on a synchronic layer [5]. In Western linguistics the following subdivision of the latter field is suggested: historical discourse analysis proper, diachronic(ally oriented) discourse analysis, and diachronic discourse analysis [3, p. 139, 140], which clearly shows differences in approaches to studies. The first one is being basically synchronically oriented studies of texts of past periods such as chronicles, documents and historical texts with the goal to discover their linguistic peculiarities at a certain time period. The second one is focused on discourse functions, text categories and their language realizations in historical perspective. The major goal of this subfield is to describe and register the development of an entire discourse domain, which requires an extensive knowledge of the inventories of text types and genres at different points in the history of language culture and this - in turn requires detailed knowledge of specific historical text types [23]. At this point researchers enter the subfields of diachronically-oriented text linguistics or text-oriented historical linguistics. The former one aims to study text types and genres as the process of formation and evolution. Scholars working within the framework of this approach make attempts to identify the repertoire of genres in some historical period and describe oral and written genres as well as transformation process of oral genres into written ones. Researchers engaged into this subfield as a rule trace the evolution of individual genres or text types (see, e.g. [13]). The latter one sets the goal to study the impact of texts, genres and discourses on the process of language change [23]. T. Köhnen sets the main objectives of this subfield as follows: 1) description of texts and genres created in past historical periods, 2) identification of formal and functional language changes in texts and genres that are needed to implement the communicative function at a certain time period, 3) showing how a change in the nature of the text functional profile affects the employed linguistic resources in historical perspective.

There is a subfield of diachronic discourse analysis, which goals are to study discourse domain, discursive categories and structures, changes in discursive functions and forms, as well as the evolution of large communicative units they are implemented in: text types, genres and discourse domains [3, p. 139-140]. This subfield, that draws on historical linguistics, text linguistics and discourse theory, is much less developed in modern linguistics. Using this approach, scholars usually have to adapt tools they have taken from general discourse theory to the needs and 
demands of their own study. Thus, diachronic discourse studies rely on separate linguistic fields such as text linguistics, pragmatics, stylistics, studies of genres from historical perspective, do not share a common methodological framework and can be classified along different axes: structural, functional, pragmatic etc. that are interrelated and provide different ways of grouping and discursive changes descriptions. The distinguishing feature of this approach is that its purpose is to trace changes in the discourse domain by analyzing evidence rather from a temporally ordered collection of texts than from texts belonging to a certain period $[21 ; 43 ; 45]$.

To sum up, there exist several approaches to historical discourse analysis. Some, being a part of historical linguistics, are tied closely to the study of language change on different language levels, others concentrate on transitions in patterns of communicative behavior, ideas and issues as they are expressed in writings of past periods. To date our knowledge of the historical stages of discourse domains are still sketchy but a foundation for later studies has been laid with the English language being the most investigated one.

In the remainder part of the article we will present another research tradition that is adopted in Russian historical linguistics and is aimed at studying the history of the Russian language in its structural and functional aspects.

\section{Diachronic perspective}

\section{in the Russian language history studies}

Diachronic studies have a long tradition in Russian linguistics. Using traditional for historical and comparative linguistics methods of language description scientists in Russian historical linguistics studied evolution of the lexical and grammatical system in the Russian language history $[12 ; 28$ 30 ; 44 et al.]. In the first decade of the $21^{\text {th }}$ cen. specialists in historical linguistics apart from formal and semantic features have turned to functional specifics of language units previously discovered in various periods in the Russian language history thus making their studies pragmatically and stylistically oriented. There were published works on functional and semantic characteristics of verbs in Old Russian [14], on dynamics of semantic and word-formation subsystems in the Russian language [10; 11 et al.]. Linguistic data are retrieved from authentic hagiographic texts, Slavonic versions of sacred texts from historical archives of Russia. For instance, on the material of hagiographic texts "Life of Theodosius of the Caves", "The Tale of Boris and Gleb" from "The Uspensky Manuscript" of the $12^{\text {th }}$ cen. functions of verbs denoting perception and emotions were studied [9], documentary texts from "Mikhailovsky Stanitsa Ataman Fund" (18 ${ }^{\text {th }}$ cen.) gave valuable information on the usage of verbs denoting visual perception and aural impression [36]. Verb functions in the $18^{\text {th }}$ cen. epistolary genre were described in [40]. Although the pragmatic approach is not clearly pronounced in the works enumerated above the analysis of linguistic data presented is supplemented by the commentaries on social and historical circumstances that influenced the choice of lexical units, their formal and functional features, which per se indicates a discursive turn in the field of Russian historical linguistics.

Besides research of lexical and grammatical means there have appeared works that are devoted to detailed descriptions of the structural aspects, grammatical, lexical, stylistic and features of text types or genres that belong to the past [24]. Several groups of researchers study documentary text archives thus discovering specific data on regional social history that is reflected in the texts, and present genre / text formation models of various text families (i.e. formal replies of the $17^{\text {th }}$ cen. from Solikamsk archive in: [8]; Don Cossack documentary text arrangement from "Mikhailovsky Stanitsa Ataman Archive Fund" (State Archive of Volgograd Region in: [15-17; 36; 39]).

Historical stylistics focuses on the changing functional profile of stylistic means considering it the main source of language change: «any language change starts in language use» [37, p. 102]. It is worth mentioning that scientists working within the approach have described related changes in language use and changes in styles of thinking, which they consider being reflected in the language, composition and structure of the text [42].

To date, there have been few and far between attempts to analyze individual genres that belong to the past historical periods. Their stylistic resources and genre features are explored in the course of a language historical development supported with extra linguistic factors (see: [41; 42 et al.]), most of the data comes from literary, newspaper and scientific texts. 
However, other genres are gradually becoming objects of research. For instance, there was a study based on the corpus of advertisements compiled from Russian provincial newspapers of the late $19^{\text {th }}$ cen. [22] that examines the balance between the informative and persuasive functions of Russian advertising discourse through analysis of performative verbs and evaluative language means. The study of Russian advertising genres evolution in the $18^{\text {th }}$ and early $20^{\text {th }}$ retrieved from early newspapers - more precisely from regional papers published in the region of South Urals [32] - allowed the author to identify the second half of the $19^{\text {th }}$ cen. as the period in which a 'colony' of genres among which a classified advertisement, a display advertisement, an advertising article, an advertising letter, obituary, a drama, an expert testimony emerged in Russian advertising discourse. Although the evolutionary nature of genre development is indicated the study uses a descriptive approach to the analysis of language means employed in different genres, thus it fails to trace the development of genre features and almost completely neglects the historical context. Besides, it is not clear whether the genres presented in the $18^{\text {th }}$ cen. Russian advertising discourse preserved in later periods or they were substituted by new genre forms.

It is worth noting that the turn of the $20^{\text {th }}$ cen. is identified in the above mentioned works as an evolution point in Russian advertising discourse history when the advertising text had acquired a persuasive function. This conclusion stays in good agreement with researches conducted on the history of English advertising discourse [43]. As far as this type of discourse functions in many languages, it allows us to make an assumption that advertising discourse might have been developing in similar ways across cultures and its genres may have evolved in close ways in different languages.

Brief overview of works and their results shows that studies are mainly restricted to the description of language and structure of genres that functioned in a specific historical period and does not investigate them from pragmatic perspective such as historical (im)politeness or conventionalized expression of various intentions and fails to reach beyond the textual evidence to the dimension of verbal interaction.

The material collected is valuable, but these investigations lack clearly defined tools of studying discourse in diachronic perspective, which implies defining systematic relations between a discourse type, its categories and their language representations contingent on social-and-cultural circumstances.

\section{Corpus-assisted diachronic discourse studies}

Recently, the thrive of corpus linguistics has led to incorporation of corpus methodology into historical linguistics studies that use corpora divided into temporally ordered stages, so-called diachronic corpora. This approach is becoming increasingly wide-spread in historical corpus linguistics ([23;26; 27] amongst many others). This development is pushed partly due to the fact that more and more resources of this kind are being developed, especially with regard to English $[2 ; 31 ; 35]$. The Helsinki Corpus, which can be said to have pioneered the genre, has been substantially expanded, and numerous other corpora now offer comparable sets of texts that represent subsequent periods of time in the development of a language. With regard to English, there is now a growing field of corpus-based historical sociolinguistics [ $33 ; 34$; 45], it investigates the role of parameters such as gender, dialect, and genre in grammatical change. Reference to these factors can make a historical analysis not only more detailed, but can also go a long way toward explaining why a given change happened the way it did. Since these parameters are annotated in at least some of the available diachronic corpora, these can be integrated as explanatory factors in quantitative historical studies.

With reference to the Russian language the National Corpus of the Russian language is a dynamically growing resource for historical language studies. It contains texts in genres of fiction, scientific prose, non-documentary prose and private correspondence from the $18^{\text {th }}$ cen. up to the present time and exemplars of old Russian language represented in the genres of prayers, chronicles, documents. Corpus-assisted discourse analysis enables linguists to define stages in discourse development and vectors of discourse domain evolution that are established on statistical analysis of changes in discourse / text parameters.

\section{Conclusion}

To sum up, historical discourse analysis has established itself as a branch at the intersection of 
historical linguistics, discourse analysis and corpus linguistics with a vast research agenda that still have many gaps to address to in order get a nuanced picture of how discourse domains have evolved by defining two types of characteristics: inherent to certain discourse types and those that have been either lost, transformed or acquired in the course of its historical development.

To date our knowledge of the historical stages of discourse domains are still sketchy but a foundation for further studies has been laid. Linguistically we need to give the minute description of a definite type/s of discourse at every period in the history of a particular language history; it has to help discover basic constitutive elements of a discourse type, distinguish specific discursive functions within socio-cultural context, define the genre repertoire of a discourse type. The second step in the diachronic discourse oriented analysis has to be aimed at comparing discourse realizations in textual and language unities in definite time periods in order to make preparations for the third step, which is aimed at tracing vectors of discourse diachronic development. At this point of comprehensive and large scale text corpus research we need to categorize various shifts and changes discovered within synchronic discourse layer comparison, to group them into some general categories and establish global trends in the discourse domain evolution. Corpus-assisted historical discourse analysis of genetically related and non-related languages and cultures can give answers to questions whether certain diachronic trends are similar and go across cultures or they are specific and unique in a cross-cultural perspective.

Finally, one more issue might be efficient in historical discourse studies, that is to relate language change that is influenced by social-andhistorical context to dynamics in cognitive structures that reflect mental construal of reality. The underlying question is whether cognitive styles are identical across time, languages and cultures.

\section{NOTES}

1 The research for this study was funded by Russian Foundation for Humanities (RGNF), 15-0400134 "Historical Discourse Studies: Issues, Methodology and Prospects".

Исследование выполнено при поддержке Российского гуманитарного научного фонда (грант
РГНФ № 15-04-00134 «Историческая дискурсология: проблемы, методология и перспективы»).

\section{REFERENCES}

1. Arutyunova N.D. Diskurs [Discourse]. Lingvisticheskyi entsiklopedicheskyi slovar [Encyclopedic Dictionary of Linguistics]. Moscow, Sovietskaya entsiklopedia Publ., 1990, pp. 136-137.

2. Beal J., Corrigan K., Moisl H. Creating and Digitizing Language Corpora, Diachronic Databases. Houndmills, Palgrave, 2007.250 p.

3. Brinton L.J. Historical discourse analysis. Schiffrin D., Tannen D., Hamilton H.E., eds. The Handbook of Discourse Analysis. Oxford, Blackwell, 2001,pp. 138-160.

4. Carroll R., Hiltunen R., Peikola M., Skaffari J., Tanskanen S-K., Valle, E., Wervik B. Introduction. Hiltunen R., Skaffari J., eds. Discourse Perspectives on English: Medieval to Modern (Pragmatics \& Beyond New Series 119). Amsterdam, Philadelphia, John Benjamins, 2003, pp. 1-12.

5. Collins D. Speech reporting and the suppression of orality in seventeenth-century Russian trial dossiers. Historical Courtroom Discourse. Special issue of Journal of Historical Pragmatics, 2006, vol. 7, no. 2, pp. 265-292.

6. Dejk van T. Yazyk. Poznaniye. Kommunikatsiya [Language. Knowledge. Communication]. Moscow, Progress Publ., 1989. 312 p.

7. Demyankov V.Z. Kognitivizm, kognitsiya, yazik, linguisticheskaya teoriya [Cognitivism, Cognition, Language and Linguistic Theory]. Yazyk $i$ struktura predstavleniya znanyy [Language and Structure of Knowledge Presentation]. Moscow, INION RAN Publ., 1991, pp. 39-77.

8. Dmitrieva E.G. Osobennosti kompozitsii i leksicheskogo sostava otpisok nachala XVII v. [Composition Properties and Lexical Peculiarities of Formal Replies of the early 17th Century]. Vestnik Volgogradskogo gosudarstvennogo universiteta. Seriya 2, Yazykoznanie [Science Journal of Volgograd State University. Linguistics], 2016, vol. 15, no. 2, pp. 81-88. DOI: http://dx.doi.org/10.15688/jvolsu2.2016.2.10.

9. Dmitrieva E.G., Safonova I.A. Glagoly vospriyatiya i emotsiy v drevnerusskom yazyke vs tekste: funktsionalno-semanticheskaya kharakteristika [Verbs of Perception and Emotions in the Old Russian Language and Text: Functional and Semantic Characteristics]. Vestnik Volgogradskogo gosudarstvennogo universiteta. Seriya 2, Yazykoznanie [Science Journal of Volgograd State University. Linguistics], 2015, no. 4(28), pp. 25-33. DOI: http://dx.doi.org/10.15688/ jvolsu2.2015.4.3.

10. Dmitrieva O.I. Dinamika glagolnoy semantikoslovoobrazovatelnoy podsistemy $\mathrm{v}$ russkom yazyke 
XVIII veka [Dynamics of Verbal Semantic and Wordformation Subsystems in the Russian Language of the 18th century]. Vestnik Volgogradskogo gosudarstvennogo universiteta. Seriya 2, Yazykoznanie [Science Journal of Volgograd State University. Linguistics], 2014, no. 1 (20), pp. 6-13.

11. Dmitrieva O.I., Yankovskiy O.I. Dinamika semantiko-slovoobrazovatelnykh podsistem russkogo yazyka: istoricheskaya dinamika slovoobrazovatelnogo gnezda [Dynamics of Semantic and Word-Formation Subsystems of the Russian Language: Historical Dynamics of the Word Family]. Vestnik Volgogradskogo gosudarstvennogo universiteta. Seriya 2, Yazykoznanie [Science Journal of Volgograd State University. Linguistics], 2015, no. 3 (27), pp. 2632. DOI: http://dx.doi.org/10.15688/jvolsu2.2015.3.3.

12. Filin F.P. Istoky $i$ sudby russkogo literaturnogo yasyka [Origin and Evolution of the Russian Literary Language]. Moscow, Nauka Publ., 1981. 326 p.

13. Fritz G. Text types in a new medium: The first newspapers (1609). Journal of Historical Pragmatics, 2001, vol. 2, no. 1, pp. 69-83.

14. Gorban O.A., Dmitrieva E.G., Kosova M.V., Safonova I.A., Terentyeva E.V., Sheptukhina E.M. Semantika drevnerusskogo glagola: sinkhronnodiakhronicheskyy aspekt [Semantics of Old Russian Verb: Synchronic and Diachronic Aspect]. Moscow, FLINTA Publ., Nauka Publ., 2015.352 p.

15. Gorban O.A. Regionalnye dokumenty XVIII veka $\mathrm{V}$ aspekte kategorii temporalnosti [Regional Documents of the 18th c. in terms of Temporality Category]. Vestnik Volgogradskogo gosudarstvennogo universiteta. Seriya 2, Yazykoznanie [Science Journal of Volgograd State University. Linguistics], 2014, no. 4 (23), pp. 7-16. DOI: http://dx.doi.org/10.15688/ jvolsu2.2014.4.1.

16. Gorban O.A., Sheptukhina E.M. Realizatsiya obyektivnoy modalnosti v tekstakh voyskovykh gramot serediny XVIII veka [Implementation of Objective Modality in Don Cossack Army Charters of the mid 18th Century]. Vestnik Volgogradskogo gosudarstvennogo universiteta. Seriya 2, Yazykoznanie [Science Journal of Volgograd State University. Linguistics], 2016, vol. 15, no. 2, pp. 34-45. DOI: http://dx.doi.org/10.15688/jvolsu2.2016.2.4.

17. Gorban O.A., Sheptukhina E.M. Regionalnye dokumenty XVIII veka: aspekty lingvisticheskogo opisaniya [Regional Documents of the 18th c.: Aspects of Linguistic Analysis]. Vestnik Volgogradskogo gosudarstvennogo universiteta. Seriya 2, Yazykoznanie [Science Journal of Volgograd State University. Linguistics], 2013, no. 3 (19), pp. 76-84.

18. Jucker A. Mass media communication: from the seventeenth to the twenty-first century. Opening Windows on Texts and Discourses of the Past. Amsterdam, John Benjamin, 2005, pp. 7-22.
19. Jucker A.H., Taavitsainen I. Diachronic speech act analysis: Insults from flyting to flaming. Journal of Historical Pragmatics, 2000, vol. 1, no. 1, pp. 67-95.

20. Kibrik A.A. Kognitivniye issledovaniya po diskursu [Cognitive Research on Discourse]. Voprosy yazykoznaniya, 1994, no. 5, pp. 126-139.

21. Kochetova L.A. Angliyskyi reklamnyi diskurs $v$ dinamicheskom aspekte [English Advertisement Discourse in Dynamic Perspective]. Volgograd, Izd-vo VolGU, 2013. 404 p.

22. Kochetova L.A., Tsynkerman T.N. Persuasive and Informative functions in Russian Advertising discourse of late XIX century. Mediterranean Journal of Social Sciences, 2015, vol. 6, no. 4 S1, pp. 358-364.

23. Köhnen T. Historical text linguistics: Investigating language change in texts and genres. Sauer H., Waxenberger G., eds. English Historical Linguistics 2008. Vol. 2: Words, Texts and Genres. Canada, John Benjamin, 2008, pp. 166-187.

24. Kosova M.V. Metod dokumentovedcheskogo analiza $\mathrm{v}$ lingvisticheskikh issledovaniyakh: soderzhanie i tseli [Documental Analysis Method in Linguistic Research: Content and Objectives]. Vestnik Volgogradskogo gosudarstvennogo universiteta. Seriya 2, Yazykoznanie [Science Journal of Volgograd State University. Linguistics], 2016, no. 1 (30), pp. 717. DOI: http://dx.doi.org/10.15688/jvolsu2.2016.1.1.

25. Kubryakova E.S. Yazyk $i$ znanie [Language and Knowledge]. Moscow, Yazyki slavyanskoy kultury Publ., 2004. 560 p.

26. Lenker U., Meurman-Solin A. Connectives in the History of English. Amsterdam, Benjamins, 2007. 318 p.

27. Lindquist H., Mair C. Corpus approaches to grammaticalization in English. Amsterdam, Benjamins, 2004. 265 p.

28. Lopushanskaya S.P. Izmeneniye semanticheskoy struktury russkikh bespristavochnikh glagolov dvizheniya $\mathrm{v}$ protsesse modulyatsii [Changes in Semantic Structure of Russian Non-prefixal Verbs of Movement in the Process of Modulation]. Russkyy glagol (v sopostavitelnom osveshchenii) [Russian Verb (in comparative perspective)]. Volgograd, Izd-vo VolGU, 1988, pp. 5-19.

29. Lopushanskaya S.P. Razgranichenie staroslovyanskogo i russkogo starotserkovnoslavyanskogo yazykov [Differentiation of Old Slavonic and Russian Church Old Slavonic Languages]. Vestnik Volgogradskogo gosudarstvennogo universiteta. Seriya 2, Yazykoznanie [Science Journal of Volgograd State University. Linguistics], 1997, vol. 2, pp. 6-17.

30. Lopushanskaya S.P. Razvitie i funktsionirovanie drevnerusskogo glagola [Evolution and Functioning of Old Russian Verb]. Volgograd, Izd-vo VolGU, 1990. 114 p.

31. MacWhinney B. The CHILDES Project: Tools for Analyzing Talk, vol. 2: The Database. Mahwah, NJ, Lawrence Erlbaum Associates, 2000. 418 p. 
32. Mironova A.A. Russkaya reklama v aspekte diakhronicheskoy stilistiki [Russian Advertising in Diachronic Stylistics Aspect]. Chelyabinsk, Izd-vo Chelyabinskogo gos. un-ta, 2011.397 p.

33. Nevalainen T., Raumolin-Brunberg H. Historical Socio-linguistics: Language Change in Tudor and Stuart England. London, Pearson Education, 2003. 266 p.

34. Nevalainen T., Raumolin-Brunberg H. Sociolinguistics and Language History. Studies based on the Corpus of Early English Correspondence. Amsterdam, Rodopi, 1996. 213 p.

35. Reppen R., Fitzmaurice S., Biber D., eds. Using Corpora to Explore Linguistic Variation. Vol. 9. Amsterdam, Benjamins Publ., 2002. 274 p.

36. Safonova I.A. Glagoly vospriyatiya v regionalnykh dokumentakh serediny XVIII veka (na materiale fonda «Mihaylovskiy stanichnyy ataman») [Verbs of Perception in Regional Documents of the middle of the 18th century (on the material of "Mikhailovsky Stanitsa Ataman" Fund)]. Vestnik Volgogradskogo gosudarstvennogo universiteta. Seriya 2, Yazykoznanie [Science Journal of Volgograd State University. Linguistics], 2016, vol. 15, no. 2, pp. 98-104. DOI: http:// dx.doi.org/10.15688/jvolsu2.2016.2.12.

37. Serebrennikov B.A., ed. Obshchee yazykoznanie. Formy yazykoznaniya, funktsii, istoriya yazyka [General Linguistics. Forms of Linguistics, Functions and History of the Language]. Moscow, Nauka Publ., 1970. 597 p.

38. Serio P. V poiskakh chetvertoy paradigmy [In Search of the fourth Paradigm]. Filosofiya v granitsakh $i$ vne granits [Philosophy within or outside the Boarders]. Kharkov, Oko Publ., pp. 37-52.
39. Sheptukhina E.M., Gorban O.A. Voyskovye gramoty serediny XVIII veka $\mathrm{v}$ aspekte kategorii modalnosti [Don Cossack Army Charters of the mid 18th cen. via the Category of Modality]. Vestnik Volgogradskogo gosudarstvennogo universiteta. Seriya 2, Yazykoznanie [Science Journal of Volgograd State University. Linguistics], 2015, no. 5 (29), pp. 718. DOI: http://dx.doi.org/10.15688/jvolsu2.2015.5.1.

40. Sheptukhina E.M., Grigoryeva S.N. Funktsii glagolnykh leksem v pismakh Dimitriya Rrostovskogo Stefanu Javorskomu [On Verb Functions in the Letters Addressed by Dimitry Rostovsky to Stefan Yavorsky]. Vestnik Volgogradskogo gosudarstvennogo universiteta. Seriya 2, Yazykoznanie [Science Journal of Volgograd State University. Linguistics], 2015, no. 4 (28), pp. 7-15. DOI: http://dx.doi.org/10.15688/jvolsu2.2015.4.1.

41. Skubalanka T. Historyczna stylistyka jкzyka polskiego [Historical Stylistics of the Polish Language]. Wrociaw, Przekroje Publ., 1984. 508 p.

42. Trosheva T.V. Formirovaniye rassuzhdenya $v$ processe razvitiya nauchnogo stilya russkogo literaturnogo yazika XVIII-XX vv. [Reasoning Formation in the Process of the 18-20th cc. Russian Literary Language Scientific Style Development]. Perm, Izd-vo Permskogo gos. un-ta, 1999. 329 p.

43. Vestergaard T. The Language of Advertising. Oxford, Blackwell, 1985. 286 p.

44. Vinogradov V.V. Izbranniye trudy $v 7$ knigah [Selected Works in 7 books]. Moscow, Nauka Publ., 1975-2006.

45. Wyss E.L. From the bridal letter to online flirting: Changes in text type from the nineteenth century to the internet era. Journal of Historical Pragmatics, 2008, vol. 9, no. 2, pp. 225-254.

\section{Information About the Authors}

Elena Yu. Ilyinova, Doctor of Sciences (Philology), Professor, Department of English Philology, Volgograd State University, Prosp. Universitetsky, 100, 400062 Volgograd, Russian Federation, ilynov@volsu.ru, english_philology@volsu.ru.

Larisa A. Kochetova, Doctor of Sciences (Philology), Associate Professor, Head of Department of English Philology, Volgograd State University, Prosp. Universitetsky, 100, 400062 Volgograd, Russian Federation, english_philology@volsu.ru, english_philolog@mail.ru.

\section{Информация об авторах}

Елена Юрьевна Ильинова, доктор филологических наук, профессор кафедры английской филологии, Волгоградский государственный университет, просп. Университетский, 100, 400062 г. Волгоград, Российская Федерация, ilynov@volsu.ru, english_philology@volsu.ru.

Лариса Анатольевна Кочетова, доктор филологических наук, доцент, заведующая кафедрой английской филологии, Волгоградский государственный университет, просп. Университетский, 100, 400062 г. Волгоград, Российская Федерация, english_philology@volsu.ru, english_philolog@mail.ru. 